\title{
Pengaruh Kecukupan Modal, Efisiensi dan Likuiditas Terhadap Rentabilitas di Bank Syariah Milik Pemerintah Indonesia
}

\author{
Effect of Capital Adequacy, Efficiency and Liquidity on \\ Rentability in Syariah Banks Owned by the Indonesian \\ Government \\ I Wayan Sunarya* \\ Program Studi Teknik Informatika, STMIK STIKOM Indonesia, Denpasar
}

${ }^{*}$ Corresponding author: e-mail: iwayansunarya@gmail.com

\begin{abstract}
Abstrak
Kinerja rasio laporan keuangan pada bank syariah merupakan salah satu faktor penentu dalam kesehatan keuangan didalam bank itu sendiri. Untuk itu perlu ada analisa pengaruh antara kecukupan modal, efisiensi dan likuiditas terhadap rentabilitas di bank syariah milik pemerintah Indonesia dari tahun 2009-2017. Penelitian ini bertujuan untuk memodelkan pengaruh antara kecukupan modal (CAR), Efisiensi (BOPO) dan Likuiditas (FDR) Terhadap Rentabilitas (ROA), kemudian menganalisis model tersebut, dan memberikan peramalan dan analisis struktural dari model tersebut. Oleh karena itu, metode yang digunakan dalam penelitian ini adalah analisis Vector Error Correction Model yang diterapkan pada data time series dari tingkat CAR, BOPO, FDR terhadap ROA. Berdasarkan spesifikasi, estimasi dan pemeriksaan model, maka diperoleh model VECM(2) sebagai model terbaik. Hasil analisis model mengatakan bahwa ada hubungan kausalitas jangka panjang dan jangka pendek antara tingkat CAR, BOPO, FDR terhadap ROA. Kemudian, berdasarkan peramalan dan analisis struktural maka dapat disimpulkan bahwa hasil yang diperoleh akurat.
\end{abstract}

Kata Kunci: Kecukupan Modal, Efisiensi, Likuiditas, Rentabilitas, Vector Error Correction Model

\begin{abstract}
The ratio of financial statements to Islamic banks is one of the determining factors in financial health within the bank itself. For this reason, it is necessary to analyze the influence of capital adequacy, efficiency and liquidity on profitability in the Indonesian state-owned Islamic banks from 2009-2017. This study aims to model the influence of capital adequacy (CAR), Efficiency (BOPO) and Liquidity (FDR) on Rentability (ROA), then analyze the model, and provide forecasting and structural analysis of the model. Therefore, the method used in this study is the analysis of Vector Error Correction Model which is applied to time series data from the level of CAR, BOPO, FDR to ROA. Based on the specification, estimation and examination of the model, the VECM (2) model was obtained as the best model. The results of the model analysis say that there is a long-term and short-term causality relationship between the levels of CAR, BOPO, FDR against ROA. Then, based on forecasting and structural analysis, it can be concluded that the results obtained are accurate.
\end{abstract}

Keywords: Capital Adequacy, Efficiency, Liquidity, Rentability, Vector Error Correction Model

How to Cite: I Wayan Sunarya. (2019). Pengaruh Kecukupan Modal, Efisiensi, dan Likuiditas Terhadap Rentabilitas di Bank Syariah Milik Pemerintah Indonesia. Jurnal Konsep Bisnis dan Manajemen, 5 (2): hal. $158-184$ 


\section{PENDAHULUAN}

Bank Sebagai lembaga keuangan merupakan badan usaha yangmenghimpun dana dari masyarakat dalam bentuk simpanan dan kemudian meyalurkan kembali dana tersebut kepada masyarakat dalam bentuk pinjaman untuk jangka waktu tertentu. Kegiatan untuk menghimpun dana sangat menentukan jumlah dana yang dapat dikembangkan oleh bank penanaman dana yang menghasilkan pendapatan bagi bank tersebut (Adli Nazrian dan Paidi Hidayat, 2012:16).

Menurut Astri Faradila dan Ari Dewi Cahyati (2013:57), kemunculan bank-bank dan lembaga keuangan untuk bank konvensional sudah diterapkan di Indonesia. Sehingga para pakar Islam membentuk bank syariah yang menurut undang-undang No.10 tahun 1998 tentang bank syariah adalah bank yang melaksanakan kegiatan usahanya berdasarkan prinsip syariah yang dalam kegiatannya memberikan jasa dalam lalu lintas pembayaran. Prinsip syariah menurut Pasal 1 ayat 13 Undang-undang No. 10 tahun 1998 tentang perbankan adalah aturan perjanjian berdasarkan hukum Islam antara bank dengan pihak lain untuk penyimpanan dana atau pembiayaan kegiatan usaha, atau kegiatan lainnya yang dinyatakan sesuai dengan syariah antara lain pembiayaan berdasarkan prinsip bagi hasil (mudharabah), pembiayaan berdasarkan prinsip penyertaan modal (musyarakah), prinsip jual beli barang dengan keuntungan (murabahah), atau pembiayaan barang modal berdasarkan prinsip sewa murni tanpa pilihan (ijarah), atau dengan adanya pilihan pemindahan kepemilikan atas barang yang disewa dari pihak bank oleh pihak lain (ijarah wa iqtina).

Sama seperti bank konvensional, bank syariah harus menjaga kinerja laporan keuangan yang dimilikinya. Analisa kinerja laporan keuangan dapat dilihat dari tingkat laporan keuangan diantara tingkat kecukupan modal (Capital Adequacy Ratio), tingkat rentabilitas atau return on asset (ROA), tingkat efisiensi atau BOPO (biaya operasional terhadap pendapatan operasional) dan tingkat likuiditas atau Finance to Deposit Ratio (FDR). Menurut Nur Gilang Giannini (2013:97) mengatakan bahwa selain dana yang tersedia (DPK), penawaran kredit perbankan juga dipengaruhi oleh persepsi bank terhadap prospek usaha debitor dan kondisi perbankan itu sendiri, seperti permodalan (CAR), jumlah kredit macet (NPL), dan Loan to Deposit Ratio (LDR), di samping itu faktor rentabilitas atau tingkat keuntungan yang tercermin dalam Return 
on Assets (ROA) juga berpengaruh terhadap kredit perbankan.

Untuk data ROA bank syariah milik pemerintah Indonesia dari tahun 2009 sampai dengan tahun 2017 yaitu Bank Mandiri Syariah (BMIS), Bank Negara Indonesia Syariah (BNIS), Bank Rakyat Indonesia Syariah (BRIS) dan Bank Tabungan Negara Syariah (BTNS) dapat dilihat sebagai berikut:

Tabel 1 Data Return On Asset (ROA) Bank Syariah Milik Pemerintah Indonesia dari Tahun 2009 - 2017 (Dalam bentuk persentase)

\begin{tabular}{|c|c|c|c|c|}
\hline Tahun & BMIS & BNIS & BRIS & BTNS \\
\hline 2009 & 2,23 & $-3,60$ & 0,53 & 1,78 \\
\hline 2010 & 2,21 & 0,61 & 0,35 & 2,05 \\
\hline 2011 & 1,95 & 1,29 & 0,20 & 2,03 \\
\hline 2012 & 2,25 & 1,48 & 1,19 & 1,94 \\
\hline 2013 & 1,53 & 1,37 & 1,15 & 1,79 \\
\hline 2014 & 0,17 & 1,27 & 0,08 & 1,14 \\
\hline 2015 & 0,56 & 1,43 & 0,76 & 1,61 \\
\hline 2016 & 0,59 & 1,44 & 0,95 & 1,76 \\
\hline 2017 & 0,59 & 1,31 & 0,51 & 1,71 \\
\hline
\end{tabular}

Sumber : Laporan Keuangan Bank Mandiri Syariah, Bank BNI Syariah, Bank BRI Syariah, Bank BTN Syariah dari tahun 2009-2017

Dari data dalam tabel 1, dapat diketahui Bank BTN Syariah memiliki tingkat tertinggi pada tahun 2017 sebesar 1,71\% dibandingkan dengan bank syariah yang lain. Hal ini berarti Bank BTN Syariah dalam menghasilkan laba bersih setelah pajak bersumber dari aset yang dimiliki sebesar 1,71\%. Data tingkat berikutnya yaitu tingkat kecukupan modal. Di dalam menjaga tingkat kecukupan modal ini, Bank Indonesia mengeluarkan peraturan No.6/10/PBI/2004. tentang Sistem
Penilaian Tingkat Kesehatan Bank Umum.

Ketentuan yang salah satu diantaranya adalah mengatur tentang permodalan Bank (Capital Adequacy Ratio) minimum sebesar 8 \% (delapan persen). Berdasarkan peraturan pemerintah mengenai tingkat kesehatan bank umum, setiap bank berusaha untuk menjaga nilai Capital Adequacy Ratio perusahaanya dengan tujuan untuk mempertahankan tingkat kesehatan Bank tersebut. Dalam implementasinya Bank Syariah milik pemerintah Indonesia tetap mengalami fluktuasi dalam perkembangan kecukupan modalnya. Hal ini terlihat dari nilai Capital Adequacy Ratio Bank Syariah milik pemerintah Indonesia periode pengamatan 20092017 pada tabel 2 berikut ini:

Tabel 2 Data Capital Adequacy Ratio (CAR) Bank Syariah Milik Pemerintah Indonesia dari Tahun 2009 - 2017 (Dalam bentuk persentase)

\begin{tabular}{|c|c|c|c|c|}
\hline Tahun & BMIS & BNIS & BRIS & BTNS \\
\hline 2009 & 12,39 & 28,80 & 17,04 & 18,23 \\
\hline 2010 & 10,60 & 27,68 & 20,62 & 16,74 \\
\hline 2011 & 14,57 & 20,67 & 14,74 & 15,03 \\
\hline 2012 & 13,82 & 19,07 & 11,35 & 17,69 \\
\hline 2013 & 14,10 & 16,23 & 14,49 & 15,62 \\
\hline 2014 & 14,76 & 18,43 & 12,89 & 14,64 \\
\hline 2015 & 12,85 & 18,11 & 13,94 & 14,64 \\
\hline 2016 & 14,01 & 17,81 & 20,63 & 20,34 \\
\hline 2017 & 15,01 & 20,14 & 20,63 & 18,87 \\
\hline
\end{tabular}

Sumber : Laporan Keuangan Bank Mandiri Syariah, Bank BNI Syariah, Bank BRI Syariah, Bank BTN Syariah dari tahun 2009-2017

Dari data tabel 2 di atas, dapat diketahui dari tahun 2009 sampai tahun 
2017 yang memiliki nilai CAR tertinggi yaitu Bank BRI Syariah di mana pada tahun 2009, Bank BRI Syariah memiliki nilai CAR sebesar 17,04\% kemudian pada tahun 2017 Bank BRI Syariah memiliki nilai CAR seb esar 20,63\%, hal ini berarti terjadi kenaikan nilai CAR Bank BRI Syariah sebesar 3,59\%.

Tingkat yang ketiga yaitu tingkat biaya operasional terhadap pendapatan operasional (BOPO) merupakan tingkat perbandingan biaya operasional terhadap pendapatan operasional. Tingkat ini digunakan untuk mengukur tingkat efisiensi dan kemampuan bank dalam melakukan kegiatan operasinya terutama kredit. Hal ini terlihat dari nilai tingkat biaya operasional terhadap pendapatan operasional (BOPO) Bank Syariah milik pemerintah Indonesia periode pengamatan 2009-2017 pada tabel 3 berikut ini:

Tabel 3 Data Biaya Operasional terhadap Pendapatan Operasional (BOPO) Bank Syariah Milik Pemerintah Indonesia dari Tahun 2009 - 2017 (Dalam bentuk persentase)

\begin{tabular}{|c|c|c|c|c|}
\hline Tahun & BMIS & BNIS & BRIS & BTNS \\
\hline 2009 & 76,88 & 135,10 & 97,50 & 87,56 \\
\hline 2010 & 82,59 & 88,05 & 98,77 & 82,39 \\
\hline 2011 & 82,04 & 90,89 & 99,25 & 81,75 \\
\hline 2012 & 73,00 & 88,79 & 86,63 & 80,74 \\
\hline 2013 & 84,03 & 88,11 & 90,42 & 82,19 \\
\hline 2014 & 100,60 & 89,80 & 99,47 & 89,19 \\
\hline 2015 & 94,78 & 89,63 & 93,79 & 84,83 \\
\hline
\end{tabular}

\begin{tabular}{|l|l|l|l|l|}
\hline 2016 & 94,12 & 86,88 & 91,33 & 82,48 \\
\hline 2017 & 94,44 & 87,62 & 95,24 & 82,06 \\
\hline
\end{tabular}

Sumber : Laporan Keuangan Bank Mandiri Syariah, Bank BNI Syariah, Bank BRI Syariah, Bank BTN Syariah dari tahun 2009-2017

Dari data pada tabel 3, dapat diketahui yang tertinggi dalam tingkat BOPO yaitu Bank BRI Syariah di mana tingkat BOPO pada tahun 2009 sebesar 97,50\% menjadi 95,24\%.

Tingkat berikutnya yaitu Finance to Deposit Ratio (FDR) menyatakan seberapa jauh kemampuan bank dalam membayar kembali penarikan dana yang dilakukan deposan dengan mengandalkan pembiayaan yang diberikan sebagai sumber likuiditasnya. Hal ini terlihat dari nilai Finance to Deposit Ratio (FDR) Bank Syariah milik pemerintah Indonesia dari tahun 20092017 pada tabel 4 berikut ini:

Tabel 4 Data Finance to Deposit Ratio (FDR) Bank Syariah Milik Pemerintah Indonesia dari Tahun 2009 - 2017 (Dalam bentuk persentase)

\begin{tabular}{|c|c|c|c|c|}
\hline Tahun & BMIS & BNIS & BRIS & BTNS \\
\hline 2009 & 83,07 & 78,25 & 120,98 & 83,75 \\
\hline 2010 & 82,54 & 68,92 & 95,82 & 108,42 \\
\hline 2011 & 86,03 & 78,60 & 90,55 & 102,56 \\
\hline 2012 & 94,40 & 84,99 & 100,96 & 100,90 \\
\hline 2013 & 89,37 & 97,86 & 102,70 & 104,42 \\
\hline 2014 & 82,13 & 92,60 & 93,90 & 108,86 \\
\hline 2015 & 81,99 & 91,94 & 84,16 & 108,78 \\
\hline 2016 & 79,19 & 84,57 & 81,47 & 102,66 \\
\hline 2017 & 77,66 & 80,21 & 71,87 & 103,13 \\
\hline
\end{tabular}

Sumber : Laporan Keuangan Bank Mandiri Syariah, Bank BNI Syariah, Bank BRI 
Syariah, Bank BTN Syariah dari tahun 2009-2017

Berdasarkan uraian di atas kondisi pertumbuhan bank syariah yang lebih cepat dibandingkan Bank Konvensional, diperlukan penelitian mengenai kesehatan bank yang salah satunya menggunakan indikator kecukupan modal. Oleh karena itu, tujuan yang ingin dicapai dalam penelitian ini yaitu:

\section{Menganalisis}

pengaruh kecukupan modal, efisiensi dan likuiditas terhadap rentabilitas Bank Syariah milik pemerintah Indonesia dari tahun 20092017.

\section{Menganalisis}

hubungan kecukupan modal, efisiensi dan likuiditas dalam jangka pendek maupun jangka panjang terhadap rentabilitas Bank Syariah milik pemerintah Indonesia dari tahun 2009-2017.

\section{METODE PENELITIAN}

Untuk metode penelitian di dalam penelitian ini dirumuskan beberapa hipotesis sebagai berikut : Apakah ada Pengaruh Kecukupan Modal, Efisiensi Dan Likuiditas Terhadap Rentabilitas di Bank Syariah milik pemerintah Indonesia dari tahun 2009 - 2017. Berdasarkan dari rumusan hipotesis tersebut maka dapat dibentuk tiga variabel sebagai berikut :
- Kecukupan modal : Capital Adequacy Ratio (CAR)

- Efisiensi : Biaya Operasional terhadap Pendapatan Opetingkatnal (BOPO)

- Likuiditas : Financing to Deposit Ratio (FDR)

- Rentabilitas : Return on Asset (ROA)

Sehingga dari penelitian ini merupakan sebuah studi kasus untuk menganalisa pengaruh CAR, BOPO dan FDR terhadap ROA di Bank Syariah milik pemerintah Indonesia dari tahun 2009 2017. Berdasarkan variabel yang sudah dibentuk, maka untuk datanya bersumber dari laporan keuangan Bank Mandiri Syariah, Bank BNI Syariah, Bank BRI Syariah dan Bank BTN Syariah dari tahun 2009-2017. Metode yang digunakan dalam penelitian ini yaitu metode VECM (Vector Error Correction Model) yang bertujuan untuk mengetahui bentuk dari keempat variabel diatas.

Menurut Lexy Janzen Sinay (2014:12), prosedur dalam analisa VECM sebagai berikut :

1. Spesifikasi estimasi, dan pemeriksaan mode

a. Uji akar unit (pemeriksaan stasineritas)

b. Uji kointegrasi Johansen

c. Estimasi dan Pemeriksaan Model

2. Analisis kausalitas 
3. Peramalan dan Analisis struktural

Hasil pengolahan data yang dilakukan pada penelitian ini menggunakan software Eviews 9.

\section{HASIL DAN PEMBAHASAN}

\section{Uji akar unit (pemeriksaan stasineritas)}

Adapun tahap pertama didalam melakukan unit root test dari keempat variabel diantaranya data ROA, CAR, BOPO dan FDR Bank Syariah milik pemerintah Indonesia dari tahun 2009-2017. Berdasarkan pengolahan data dengan menggunakan Eview 9, diperoleh hasil output sebagai berikut:

Tabel 5 Unit Root Test (Augmented DickeyFuller test statistic) untuk level

\begin{tabular}{|c|c|c|c|}
\hline \multirow{2}{*}{ Data } & $\begin{array}{c}\text { Critical } \\
\text { Value }\end{array}$ & \multicolumn{2}{|c|}{ Level } \\
\cline { 2 - 4 } & $(\alpha)$ & Stat. ADF & p value \\
\hline ROA & & $-2,312365$ & 0,1744 \\
\hline & $5 \%$ & $-2,957110$ & \\
\hline & & & \\
\hline CAR & & $-0,948478$ & 0,7587 \\
\hline & $5 \%$ & $-2,960411$ & \\
\hline & & & $-2,739522$ \\
\hline BOPO & & $-2,957110$ & 0,0786 \\
\hline & $5 \%$ & & \\
\hline & & $-1,153066$ & 0,6821 \\
\hline FDR & & $-2,957110$ & \\
\hline & $5 \%$ & & \\
\hline & & & \\
\hline
\end{tabular}

Sumber : Tabel 1, 2, 3, 4 (Data diproses)

Berdasarkan Tabel 5 dapat dibuat analisa bahwa data ROA, CAR, BOPO dan FDR di
Bank Syariah milik pemerintah Indonesia dari tahun 2009-2017 merupakan data yang mengandung akar unit pada level atau tidak stasioner pada level. Hal ini dapat dilihat dari teknik test unit root yang dilakukan yaitu teknik level terlihat $\mathrm{p}$ value statistik ADF untuk masingmasing variabel lebih besar dari $\alpha=5 \%$, hal ini berarti menerima hipotesis HO yaitu terdapat akar unit pada data atau data tidak stasioner. Sementara itu, dari hasil diferensi pertama dapat dilihat pada $\mathrm{p}$ value statistik ADF dari masing-masing variabel lebih kecil dari $\alpha=5 \%$, ini artinya menolak hipotesis $H_{0}$ yaitu data tidak mengandung akar unit atau sudah stasioner. Dengan demikian, variabel ROA, CAR, BOPO dan FDR merupakan variabel non stationer orde pertama.

\section{Uji Kointegrasi Johansen}

Hasil uji kointegrasi dengan menggunakan lag 2 (lag signifikan berdasarkan prosedur VAR) dari variabel ROA, CAR, BOPO dan FDR dengan menggunakan statisik trace dan statistik nilai Eigen maksimum dapat dilihat pada tabel 6 dan tabel 7. Pada tabel 6 dapat dilihat bahwa, hasil uji hipotesis dengan menggunakan statistik trace untuk hipotesis : 
$\mathrm{H}_{0}$ : Tidak ada persaman kointegrasi

$P$ value adalah 0,0000 lebih kecil dari $\alpha=$ $5 \%$ (Nilai statistik trace yaitu 89,93052 lebih besar dari nilai 47,85613 tabelnya pada $\alpha=5 \%$ ). Ini artinya hipotesis $\mathrm{H}_{0}$ ditolak. Dengan demikian, dapat dibuat kesimpulan bahwa ada persamaan kointegrasi. Untuk itu, dilakukan pemeriksaan untuk hipotesis berikutnya:

Tabel 6. Johansen Cointegration Test

\begin{tabular}{|c|c|c|c|c|}
\hline $\begin{array}{c}\text { Hipotesis: } \\
\text { r }\end{array}$ & $\begin{array}{c}\text { Nilai } \\
\text { Eigen }\end{array}$ & $\begin{array}{c}\text { Trace } \\
\text { Statistic }\end{array}$ & $\begin{array}{c}\text { Critical } \\
\text { value } \\
(\alpha=5 \%)\end{array}$ & $\begin{array}{c}\mathrm{p}^{-} \\
\text {value }\end{array}$ \\
\hline o & 0,78 & 89,93 & 47,86 & 0,00 \\
\hline 1 & 0,55 & 40,53 & 42,80 & 0,06 \\
\hline 2 & 0,31 & 14,41 & 15,49 & 0,07 \\
\hline 3 & 0,06 & 2,07 & 3,84 & 0,15 \\
\hline
\end{tabular}

Sumber : Tabel 1, 2, 3, 4 (Data diproses)

Berdasarkan pada Tabel 6, akan diperiksa hasil uji hipotesis berikut ini :

$\mathrm{H}_{0}$ : Ada persamaan kointegrasi

$\mathrm{H}_{1}$ : Tidak ada persamaan kointegrasi

Pada tabel 6 dapat dilihat nilai p-value untuk masing-masing hipotesis adalah 0,000 lebih kecil dari nilai $\alpha=5 \%$ (statistik trace lebih besar dari nilai kritisnya pada saat $\alpha=5 \%$ untuk masingmasing hipotesis). Hal ini berarti bahwa $\mathrm{H}_{0}$ diterima. Dengan demikian, berdasarkan analisa tersebut dapat dibuat kesimpulan bahwa hasil uji kointegrasi dengan menggunakan statistik trace mengindikasikan bahwa minimal ada satu persamaan kointegrasi yang dapat dibentuk.
Tabel 7. Johansen Cointegration Test (Maximum)

\begin{tabular}{|c|c|c|c|c|}
\hline $\begin{array}{c}\text { Hipotesis: } \\
\text { r }\end{array}$ & $\begin{array}{c}\text { Nilai } \\
\text { Eigen }\end{array}$ & $\begin{array}{c}\text { Trace } \\
\text { Statistic }\end{array}$ & $\begin{array}{c}\text { Critical } \\
\text { value } \\
(\alpha=5 \%)\end{array}$ & $\begin{array}{c}\mathrm{p}- \\
\text { value }\end{array}$ \\
\hline o & 0,78 & 49,40 & 27,58 & 0,00 \\
\hline 1 & 0,55 & 26,12 & 28,13 & 0,08 \\
\hline 2 & 0,31 & 12,34 & 14,26 & 0,09 \\
\hline 3 & 0,06 & 2,07 & 3,8 & 0,15 \\
\hline
\end{tabular}

Sumber : Tabel 1, 2, 3, 4 (Data diproses)

Dari data yang terdapat pada tabel 7 dapat dilihat bahwa hasil uji hipotesis dengan menggunakan statistik nilai Eigen maksimum, yaitu p-value statistik trace untuk masing-masing hipotesis :

$\mathrm{H}_{0}$ : Ada persamaan kointegrasi

$\mathrm{H}_{1}$ : Tidak ada persamaan kointegrasi

Nilai p-value pada tabel 7 terlihat jelas bahwa terdapat satu kointegrasi yaitu nilai p-value sebesar 0,0000 lebih besar dari nilai $\alpha=0,05$; hal ini berarti $\mathrm{H}_{0}$ diterima.

\section{Estimasi dan Pemeriksaan Model}

Setelah melakukan analisa kointegrasi, dilanjutkan dengan melakukan analisa dalam pemilihan lag optimum. Pemilihan lag optimum dalam VECM dapat menggunakan kriteria informasi, yaitu Akaike Information Criterion (AIC) dan Schwarz Information Criterion (SC). Hasil pengolahan data dengan menggunakan analisa Akaike Information Criterion (AIC) dan Schwarz Information Criterion (SC) untuk lag satu sampai dengan lag delapan dapat dilihat 
pada tabel 8. Perlu diketahui bahwa penggunaan lag satu sampai dengan lag delapan dikarenakan prinsip parsimony (kesederhanaan model) dalam permodelan statistika, hal ini disebabkan oleh semakin banyak lag yang digunakan, maka koefisien parameter model semakin banyak.

Tabel 8. Information Criteria

\begin{tabular}{|c|c|c|}
\hline Lag & $\begin{array}{c}\text { Akaike } \\
\text { Information } \\
\text { Criterion (AIC) }\end{array}$ & $\begin{array}{c}\text { Schwarz } \\
\text { Information } \\
\text { Criterion }(S C)\end{array}$ \\
\hline 1 & 20,02776 & 20,91653 \\
\hline 2 & 18,04871 & $19,29337^{*}$ \\
\hline 3 & $16,29051^{*}$ & 19,66485 \\
\hline 4 & 16,93523 & 19,40520 \\
\hline
\end{tabular}

Sumber : Tabel 1, 2, 3, 4 (Data diproses)

Pada tabel 8 dapat dilihat bahwa lag 3 memiliki nilai AIC terkecil, sedangkan lag 2 memiliki nilai SC terkecil. Dengan demikian lag 2 dan lag 3 akan digunakan untu proses estimasi parameter Vector Error Correction Model (VECM). Berdasarkan hasil analisis lag optimum tersebut, maka bentuk persamaan VECM yang diestimasi adalah $\operatorname{VECM(2)~dan~}$ $\operatorname{VECM(3),~masing-masing~dengan~jumlah~}$ persamaan kointegrasi adalah dua. Kemudian dilakukan pemeriksaan model dengan memilih model terbaik antara $\operatorname{VECM(2)~dan~VECM(3).~Pemeriksaan~}$ model yang dilakukan dengan menggunakan analisa uji asumsi residual dari kedua model tersebut, yaitu uji serial korelasi residual seperti yang ditunjukkan dalam tabel 9 berikut ini:

Tabel 9. Portmanteau Test on VECM(2)

\begin{tabular}{|c|c|c|c|}
\hline \multirow{2}{*}{ Lag } & \multicolumn{3}{|c|}{ VECM(2) } \\
\cline { 2 - 4 } & Stat. Q & p value & df \\
\hline 1 & 16,46283 & NA $^{*}$ & NA $^{*}$ \\
\hline 2 & 36,09632 & NA $^{*}$ & NA $^{*}$ \\
\hline 3 & 54,29685 & 0,1345 & 16 \\
\hline 4 & 73,48157 & 0,1564 & 32 \\
\hline 5 & 86,86297 & 0,2165 & 48 \\
\hline 6 & 104,6527 & 0,2453 & 64 \\
\hline 7 & 110,1408 & 0,2675 & 80 \\
\hline 8 & 124,3054 & 0,3123 & 96 \\
\hline 9 & 135,0840 & 0,3453 & 112 \\
\hline 10 & 146,2771 & 0,3564 & 128 \\
\hline 11 & 156,3912 & 0,3675 & 144 \\
\hline 12 & 164,7442 & 0,3876 & 160 \\
\hline
\end{tabular}

Sumber : Tabel 1, 2, 3, 4 (Data diproses)

Tabel 9 (Lanjutan). Portmanteau Test on $\operatorname{VECM}(3)$

\begin{tabular}{|c|c|c|c|}
\hline \multirow{2}{*}{ Lag } & \multicolumn{3}{|c|}{$\operatorname{VECM}(3)$} \\
\cline { 2 - 4 } & Stat. Q & p value & df \\
\hline 1 & 15,39711 & NA $^{*}$ & NA $^{*}$ \\
\hline 2 & 33,28613 & NA $^{*}$ & NA $^{*}$ \\
\hline 3 & 47,66786 & NA $^{*}$ & NA $^{*}$ \\
\hline 4 & 62,66859 & 0,0165 & 16 \\
\hline 5 & 78,70373 & 0,0187 & 32 \\
\hline 6 & 100,3596 & 0,0265 & 48 \\
\hline 7 & 115,5666 & 0,0365 & 64 \\
\hline 8 & 136,2712 & 0,0386 & 80 \\
\hline 9 & 145,5644 & 0,0653 & 96 \\
\hline 10 & 154,4738 & 0,0754 & 112 \\
\hline 11 & 165,0873 & 0,0875 & 128 \\
\hline 12 & 177,4790 & 0,0894 & 144 \\
\hline
\end{tabular}
Sumber : Tabel 1, 2, 3, 4 (Data diproses)

Pada tabel 9, dapat dilihat bahwa hasil uji Portmanteau untuk $\operatorname{VECM}(2)$ tidak mengandung serial korelasi residual pada setiap lag. Sedangkan untuk VECM(3) menyatakan bahwa model tersebut mengandung serial korelasi residual pada lag 4,5,6,7,8, dimana lag 3 p-value dari statistik- $Q$ 
untuk lag kurang dari taraf signifikansi $\alpha$ $=5 \%$ (artinya menolak $\mathrm{H}_{0}$ : tidak ada serial korelasi). Dengan demikian, $\operatorname{VECM(2)~lebih~baik~dibandingkan~}$ $\operatorname{VECM(3)~karena~tidak~terdapat~serial~}$ korelasi residual. Hal ini berarti bahwa $\operatorname{VECM(2)~merupakan~model~terbaik.~}$

$$
\begin{aligned}
\Delta \mathrm{ROA}_{\mathrm{t}}= & -1,692\left(\mathrm{ROA}_{\mathrm{t}}-1-0,075 \mathrm{CAR}_{\mathrm{t}-1}\right. \\
& +0,092 \mathrm{BOPO}_{\mathrm{t}-1}-0,040 \text { FDR }_{\mathrm{t}-1} \\
& -4,496)-0,308 \Delta \mathrm{ROA}_{\mathrm{t}-1} \\
& -0,127 \Delta \mathrm{ROA}_{\mathrm{t}-2}+0,071 \Delta \mathrm{CAR}_{\mathrm{t}-1} \\
& +0,095 \Delta \mathrm{CAR}_{\mathrm{t}-2}+0,007 \Delta \mathrm{BOPO}_{\mathrm{t}-1} \\
& +0,020 \Delta \mathrm{BOPO}_{\mathrm{t}-2}+0,045 \Delta \mathrm{FDR}_{\mathrm{t}-1} \\
& +0,064 \Delta \text { FDR }_{\mathrm{t}-2}+0,082 \quad(1) \\
\Delta \mathrm{CARt}= & -1,900 \mathrm{ROA}_{\mathrm{t}-1}-0,075 \mathrm{CAR}_{\mathrm{t}-1} \\
& +0,092 \mathrm{BOPO}_{\mathrm{t}-1}-0,040 \mathrm{FDR}_{\mathrm{t}-1} \\
& -4,496)-8,562 \Delta \mathrm{ROA}_{\mathrm{t}-1} \\
& -4,909 \Delta \mathrm{ROA}_{\mathrm{t}-2}-1,056 \Delta \mathrm{CAR}_{\mathrm{t}-1} \\
& -0,318 \Delta \mathrm{CAR}_{\mathrm{t}-2}-0,909 \Delta \mathrm{BOPO}_{\mathrm{t}-1} \\
& -0,436 \Delta \mathrm{BOPO}_{\mathrm{t}-2}-0,145 \Delta \mathrm{FDR}_{\mathrm{t}-1} \\
& -0,149 \Delta \text { FDR }_{\mathrm{t}-2}-0,198 \quad(2)
\end{aligned}
$$

$\Delta \mathrm{BOPO}_{\mathrm{t}}=-27,912\left(\mathrm{ROA}_{\mathrm{t}-1}-0,075 \mathrm{CARt}-1\right.$

$+0,092$ BOPO $_{\mathrm{t}-1}-0,040$ FDR $_{\mathrm{t}-1}$

$-4,496)+1,357 \Delta \mathrm{ROA}_{\mathrm{t}-1}$

$+2,230 \Delta \mathrm{ROA}_{\mathrm{t}-2}-0,905 \Delta \mathrm{CAR}_{\mathrm{t}-1}$

$-0,805 \Delta$ CAR $_{\mathrm{t}-2}-0,237 \Delta \mathrm{BOPO}_{\mathrm{t}-1}$

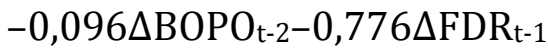

$-0,743 \Delta$ FDRt $-2^{-1,077}$

$\Delta \mathrm{FDR}_{\mathrm{t}}=-33,288\left(\mathrm{ROA}_{\mathrm{t}-1}-0,075 \mathrm{CAR}_{\mathrm{t}-1}\right.$

$+0,092$ BOPO $_{\mathrm{t}-1}-0,040$ FDR $_{\mathrm{t}-1}$

$-4,496)-8,166 \Delta \mathrm{ROA}_{\mathrm{t}-1}$

$+7,830 \Delta \mathrm{ROAt}_{\mathrm{t}-2}+3,320 \Delta \mathrm{CAR}_{\mathrm{t}-1}$

$+2,288 \Delta$ CARt $_{\mathrm{t}-2}-0,059 \Delta$ BOPO $_{\mathrm{t}-1}$

$+0,834 \Delta$ BOPO $_{\mathrm{t}-2}+0,726 \Delta$ FDR $_{\mathrm{t}-1}$

$+0,681 \Delta \mathrm{FDR}_{\mathrm{t}-2}+0,836$

Analisis Kausalitas Granger
Analisis Kausalitas Granger untuk Variabel Dependen $\triangle$ ROAt

Berdasarkan bentuk persamaan (1) model VECM(2) di atas, diketahui bahwa variabel ROA memiliki persamaan kointegrasi -1,692, dimana koefisien error correction term (ECT) bertanda negatif. Berdasarkan hasil pengolahan data dengan menggunakan Eviews 9 diperoleh bahwa untuk p-value statistik F sebesar 0,000031 kurang dari taraf signifikansi $\alpha=5 \%$, yang berarti bahwa koefisien yang signifikan. Dengan demikian, koefisien ECT pada persamaan (1) merupakan koefisien yang signifikan dan bertanda negatif. Hal ini berarti terdapat hubungan kausalitas jangka panjang (long-run causality) dari CAR, BOPO dan FDR terhadap tingkat ROA di Bank Syariah milik pemerintah Indonesia dari tahun 2009-2017. Hasil ini didukung oleh penelitian yang dilakukan oleh Mawardi (2005) yang menyatakan bahwa CAR memiliki hubungan kausalitas jangka panjang terhadap ROA.

Menurut Lexy Janzen Sinay (2014:14) untuk melihat hubungan kausalitas jangka pendek (short-run causality) pada sebuah persamaan VECM maka digunakan uji kausalitas Granger. Adapun hasil uji kausalitas Granger pada 
persamaan pertama dari $\operatorname{VECM}(2)$ yaitu sebagai berikut :

Tabel 10. Granger Causality Test: Dependent Variable $\Delta \mathrm{ROA}_{\mathrm{t}}$

\begin{tabular}{|l|c|c|c|}
\hline \multicolumn{1}{|c|}{ Excluded } & Chi-sq & $\mathrm{df}$ & $\mathrm{p}$ value \\
\hline$\Delta \mathrm{CAR}_{\mathrm{t}}$ & 9,512895 & $\mathbf{2}$ & $\mathrm{o}, \mathrm{oo} 86$ \\
\hline$\Delta \mathrm{BOPO}_{\mathrm{t}}$ & 0,253455 & 2 & 0,8810 \\
\hline$\Delta \mathrm{FDR}_{\mathrm{t}}$ & $\mathbf{2 8 , 7 2 8 1 9}$ & $\mathbf{2}$ & o, o00o \\
\hline All & 57,61088 & 6 & o,oooo \\
\hline
\end{tabular}

Sumber : Persamaan VECM(2) - $\triangle$ ROA $_{t}$

Pada tabel 10, dapat dibuat suatu analisa yaitu $p$-value statistik uji Wald yaitu :

1) Variabel $\triangle$ CARt $_{\mathrm{t}}$ adalah 0,0086 lebih kecil dari taraf signifikan $\alpha=5 \%$. Hal ini berarti bahwa, menolak hipotesis $\mathrm{H}_{0}$ : tidak ada hubungan kausalitas jangka pendek yang artinya ada hubungan kausalitas jangka pendek antara tingkat CAR terhadap tingkat ROA di Bank Syariah milik pemerintah Indonesia dari tahun 2009-2017.

2) Untuk variabel $\triangle \mathrm{BOPO}_{\mathrm{t}}$ memiliki nilai p-value sebesar 0,8810 lebih besar dari taraf signifikan $\alpha=5 \%$. Hal ini berarti bahwa, menerima hipotesis $\mathrm{H}_{0}$ : tidak ada hubungan kausalitas jangka pendek yang artinya tidak ada hubungan kausalitas jangka pendek antara tingkat BOPO terhadap tingkat ROA di Bank Syariah milik pemerintah Indonesia dari tahun 2009-2017.

3) Selanjutnya untuk variabel $\triangle F D R_{t}$ memiliki nilai $p$-value sebesar 0,0000 lebih kecildari taraf signifikan $\alpha=5 \%$. Hal ini berarti bahwa, menolak hipotesis $\mathrm{H}_{0}$ : tidak ada hubungan kausalitas jangka pendek yang artinya ada hubungan kausalitas jangka pendek antara tingkat FDR terhadap tingkat ROA di Bank Syariah milik pemerintah Indonesia dari tahun 2009-2017.

Namun, jika dilihat secara keseluruhan pada persamaan (1), maka terdapat hubungan kausalitas jangka pendek dari tingkat CAR, BOPO dan FDR terhadap tingkat ROA di Bank Syariah milik pemerintah Indonesia dari tahun 2009-2017. Hal ini dapat dilihat dari nilai $p$-value $=0,0000$ lebih kecil dari taraf signifikan $\alpha=5 \%$, yang artinya menolak hipotesis $\mathrm{H}_{0}$ di mana hal ini berarti terdapat hubungan kausalitas jangka pendek antara tingkat CAR, BOPO dan FDR terhadap tingkat ROA di Bank Syariah milik pemerintah Indonesia dari tahun 2009-2017. Hal ini sesuai dengan penelitian yang dilakukan oleh Anita Karisma Mastika Permatasari dan Dheasey Amboningtyas (2017).

Analisis Kausalitas Granger untuk Variabel Dependen $\triangle C A R_{t}$ 
Berdasarkan bentuk persamaan (2) model VECM(2) di atas, diketahui bahwa variabel CAR memiliki persamaan kointegrasi -1,900; di mana koefisien error correction term (ECT) bertanda negatif. Berdasarkan hasil pengolahan data dengan menggunakan Eviews 9 diperoleh bahwa untuk $p$-value statistik $\mathrm{F}$ sebesar 0,000001 kurang dari taraf signifikansi $\alpha=5 \%$, yang berarti bahwa koefisien yang signifikan. Dengan demikian, koefisien ECT pada persamaan (2) merupakan koefisien yang signifikan dan bertanda negatif. Hal ini berarti terdapat hubungan kausalitas jangka panjang (long-run causality) dari ROA, BOPO dan FDR terhadap tingkat CAR di Bank Syariah milik pemerintah Indonesia dari tahun 2009-2017. Hal ini sesuai dengan penelitian yang dilakukan oleh Fenandi Bilian dan Purwanto (2017).

Menurut Lexy Janzen Sinay (2014:14) untuk melihat hubungan kausalitas jangka pendek (short-run causality) pada sebuah persamaan VECM maka digunakan uji kausalitas Granger. Adapun hasil uji kausalitas Granger pada persamaan pertama dari $\operatorname{VECM}(2)$ yaitu sebagai berikut :

Tabel 11. Granger Causality Test: Dependent Variable $\Delta$ CARt

\begin{tabular}{|l|c|c|c|}
\hline Excluded & Chi-sq & Df & p value \\
\hline$\Delta$ ROAt & $\mathbf{1 8 , 2 3 4 9 5}$ & $\mathbf{2}$ & o,ooo1 \\
\hline
\end{tabular}

\begin{tabular}{|l|l|l|l|}
\hline$\Delta$ BOPOt & 18,09765 & $\mathbf{2}$ & 0,0001 \\
\hline$\Delta$ FDRt & 6,079053 & $\mathbf{2}$ & 0,0479 \\
\hline All & 39,01579 & 6 & 0,0000 \\
\hline
\end{tabular}

Sumber : Persamaan VECM(2) - $\triangle$ CARt

Pada tabel 11, dapat dibuat suatu analisa yaitu $p$-value statistik uji Wald yaitu :

1) Variabel $\triangle \mathrm{ROA}$ adalah 0,0001 lebih kecil dari taraf signifikan $\alpha=5 \%$. Hal ini berarti bahwa, menolak hipotesis $\mathrm{H}_{0}$ : tidak ada hubungan kausalitas jangka pendek yang artinya ada hubungan kausalitas jangka pendek antara tingkat ROA terhadap tingkat CAR di Bank Syariah milik pemerintah Indonesia dari tahun 2009-2017.

2) Untuk variabel $\triangle B O P O_{t}$ memiliki nilai p-value sebesar 0,0001 lebih kecil dari taraf signifikan $\alpha=5 \%$. Hal ini berarti bahwa, menolak hipotesis $\mathrm{H}_{0}$ : tidak ada hubungan kausalitas jangka pendek yang artinya ada hubungan kausalitas jangka pendek antara tingkat BOPO terhadap tingkat CAR di Bank Syariah milik pemerintah Indonesia dari tahun 2009-2017.

3) Selanjutnya untuk variabel $\Delta \mathrm{FDR}_{\mathrm{t}}$ memiliki nilai $p$-value sebesar 0,0479 lebih kecil dari taraf signifikan $\alpha=$ 5\%. Hal ini berarti bahwa, menolak hipotesis $\mathrm{H}_{0}$ : tidak ada hubungan kausalitas jangka pendek yang artinya ada hubungan kausalitas 
jangka pendek antara tingkat FDR terhadap tingkat CAR di Bank Syariah milik pemerintah Indonesia dari tahun 2009-2017.

Namun, jika dilihat secara keseluruhan pada persamaan (2), maka terdapat hubungan kausalitas jangka pendek dari tingkat ROA, BOPO dan FDR terhadap tingkat CAR di Bank Syariah milik pemerintah Indonesia dari tahun 2009-2017. Hal ini dapat dilihat dari nilai $p$-value $=0,0000$ lebih kecil dari taraf signifikan $\alpha=5 \%$, yang artinya menolak hipotesis $\mathrm{H}_{0}$ di mana hal ini berarti terdapat hubungan kausalitas jangka pendek antara tingkat ROA, BOPO dan FDR terhadap tingkat CAR di Bank Syariah milik pemerintah Indonesia dari tahun 2009-2017. Hal ini didukung oleh penelitian yang dilakukan oleh Rofikoh Rokhim dan Jubilant Arda Harmidy (2013).

Analisis Kausalitas Granger untuk Variabel Dependen $\triangle \mathrm{BOPO}_{\mathrm{t}}$

Berdasarkan bentuk persamaan (3) model VECM(2) di atas, diketahui bahwa variabel BOPO memiliki persamaan kointegrasi -27,912; di mana koefisien error correction term (ECT) bertanda negatif. Berdasarkan hasil pengolahan data dengan menggunakan Eviews 9 diperoleh bahwa untuk $p$-value statistik $\mathrm{F}$ sebesar 0,000002 kurang dari taraf signifikansi $\alpha=5 \%$, yang berarti bahwa koefisien yang signifikan. Dengan demikian, koefisien ECT pada persamaan (3) merupakan koefisien yang signifikan dan bertanda negatif. Hal ini berarti terdapat hubungan kausalitas jangka panjang (long-run causality) dari ROA, CAR dan FDR terhadap tingkat BOPO di Bank Syariah milik pemerintah Indonesia dari tahun 2009-2017. Hal ini sesuai dengan penelitian yang dilakukan oleh Deden Edwar Yokeu Bernardin (2016).

Menurut Lexy Janzen Sinay (2014:14) untuk melihat hubungan kausalitas jangka pendek (short-run causality) pada sebuah persamaan VECM maka digunakan uji kausalitas Granger. Adapun hasil uji kausalitas Granger pada persamaan pertama dari VECM(2) yaitu sebagai berikut :

Tabel 12. Granger Causality Test: Dependent Variable $\triangle \mathrm{BOPO}_{\mathrm{t}}$

\begin{tabular}{|l|c|c|c|}
\hline Excluded & Chi-sq & df & p value \\
\hline$\Delta$ ROAt & 0,322428 & 2 & 0,8511 \\
\hline$\Delta$ CARt & 8,221816 & 2 & 0,0164 \\
\hline$\Delta$ FDRt & 40,28180 & 2 & 0,0000 \\
\hline All & 71,83938 & 6 & 0,0000 \\
\hline
\end{tabular}

Sumber : Persamaan VECM(2) - $\triangle$ BOPOt $_{t}$

Pada tabel 12, dapat dibuat suatu analisa yaitu $p$-value statistik uji Wald yaitu : 
1) Variabel $\triangle \mathrm{ROA}$ adalah 0,8511 lebih besar dari taraf signifikan $\alpha=5 \%$. Hal ini berarti bahwa, menerima hipotesis $\mathrm{H}_{0}$ : tidak ada hubungan kausalitas jangka pendek yang artinya tidak ada hubungan kausalitas jangka pendek antara tingkat ROA terhadap tingkat BOPO di Bank Syariah milik pemerintah Indonesia dari tahun 2009-2017.

2) Untuk variabel $\Delta C A R_{t}$ memiliki nilai p-value sebesar 0,0164 lebih kecil dari taraf signifikan $\alpha=5 \%$. Hal ini berarti bahwa, menolak hipotesis $\mathrm{H}_{0}$ : tidak ada hubungan kausalitas jangka pendek yang artinya ada hubungan kausalitas jangka pendek antara tingkat CAR terhadap tingkat BOPO di Bank Syariah milik pemerintah Indonesia dari tahun 2009-2017.

3) Selanjutnya untuk variabel $\Delta F R_{t}$ memiliki nilai $p$-value sebesar 0,000 lebih kecil dari taraf signifikan $\alpha=$ 5\%. Hal ini berarti bahwa, menolak hipotesis $\mathrm{H}_{0}$ : tidak ada hubungan kausalitas jangka pendek yang artinya ada hubungan kausalitas jangka pendek antara tingkat FDR terhadap tingkat BOPO di Bank Syariah milik pemerintah Indonesia dari tahun 2009-2017.
Namun, jika dilihat secara keseluruhan pada persamaan (3), maka terdapat hubungan kausalitas jangka pendek dari tingkat ROA, CAR dan FDR terhadap tingkat BOPO di Bank Syariah milik pemerintah Indonesia dari tahun 2009-2017. Hal ini dapat dilihat dari nilai $p$-value $=0,0000$ lebih kecil dari taraf signifikan $\alpha=5 \%$, yang artinya menolak hipotesis $\mathrm{H}_{0}$ di mana hal ini berarti terdapat hubungan kausalitas jangka pendek antara tingkat ROA, CAR dan FDR terhadap tingkat BOPO di Bank Syariah milik pemerintah Indonesia dari tahun 2009-2017.

Analisis Kausalitas Granger untuk Variabel Dependen $\triangle F D R_{t}$

Berdasarkan bentuk persamaan (4) model VECM(2) diatas, diketahui bahwa variabel FDR memiliki persamaan kointegrasi -33,288; di mana koefisien error correction term (ECT) bertanda negatif. Berdasarkan hasil pengolahan data dengan menggunakan Eviews 9 diperoleh bahwa untuk $p$-value statistik $\mathrm{F}$ sebesar 0,000000 kurang dari taraf signifikansi $\alpha=5 \%$, yang berarti bahwa koefisien yang signifikan. Dengan demikian, koefisien ECT pada persamaan (4) merupakan koefisien yang signifikan dan bertanda negatif. Hal ini berarti 
terdapat hubungan kausalitas jangka panjang (long-run causality) dari ROA, CAR dan BOPO terhadap tingkat FDR di Bank Syariah milik pemerintah Indonesia dari tahun 2009-2017. Hal ini sesuai dengan penelitian yang dilakukan oleh Erma Kurniasih (2016).

Menurut Lexy Janzen Sinay (2014:14) untuk melihat hubungan kausalitas jangka pendek (short-run causality) pada sebuah persamaan VECM maka digunakan uji kausalitas Granger. Adapun hasil uji kausalitas Granger pada persamaan pertama dari $\operatorname{VECM(2)~yaitu~}$ sebagai berikut :

Tabel 13. Granger Causality Test: Dependent Variable $\Delta$ FDRt

\begin{tabular}{|l|c|c|c|}
\hline Excluded & Chi-sq & df & p value \\
\hline$\sum$ ROAt & 11,83162 & 2 & 0,0027 \\
\hline$\sum$ CARt & 37,87209 & 2 & 0,0000 \\
\hline$\sum$ BOPOt & 4,282536 & 2 & 0,1175 \\
\hline All & 101,1076 & 6 & o,oooo \\
\hline
\end{tabular}

Sumber : Persamaan VECM(2) - $\triangle$ FDR $_{\mathrm{t}}$

Pada tabel 13, dapat dibuat suatu analisa yaitu $p$-value statistik uji Wald yaitu :

1) Variabel $\triangle \mathrm{ROAt}$ adalah 0,0027 lebih kecil dari taraf signifikan $\alpha=5 \%$. Hal ini berarti bahwa, menolak hipotesis $\mathrm{H}_{0}$ : tidak ada hubungan kausalitas jangka pendek yang artinya ada hubungan kausalitas jangka pendek antara tingkat ROA terhadap tingkat FDR di Bank Syariah milik pemerintah Indonesia dari tahun 2009-2017.

2) Untuk variabel $\Delta \mathrm{CAR}_{\mathrm{t}}$ memiliki nilai $p$-value sebesar 0,0000 lebih kecil dari taraf signifikan $\alpha=5 \%$. Hal ini berarti bahwa, menolak hipotesis $\mathrm{H}_{0}$ : tidak ada hubungan kausalitas jangka pendek yang artinya ada hubungan kausalitas jangka pendek antara tingkat CAR terhadap tingkat FDR di Bank Syariah milik pemerintah Indonesia dari tahun 2009-2017.

3) Selanjutnya untuk variabel $\triangle \mathrm{BOPO}_{\mathrm{t}}$ memiliki nilai $p$-value sebesar 0,1175 lebih besar dari taraf signifikan $\alpha=$ 5\%. Hal ini berarti bahwa, menerima hipotesis $\mathrm{H}_{0}$ : tidak ada hubungan kausalitas jangka pendek yang artinya tidak ada hubungan kausalitas jangka pendek antara tingkat BOPO terhadap tingkat FDR di Bank Syariah milik pemerintah Indonesia dari tahun 2009-2017.

Namun, jika dilihat secara keseluruhan pada persamaan (4), maka terdapat hubungan kausalitas jangka pendek dari tingkat ROA, CAR dan BOPO terhadap tingkat FDR di Bank Syariah milik pemerintah Indonesia dari tahun 20092017. Hal ini dapat dilihat dari nilai $p$ - 
value $=0,0000$ lebih kecil dari taraf signifikan $\alpha=5 \%$, yang artinya menolak hipotesis $\mathrm{H}_{0}$ di mana hal ini berarti terdapat hubungan kausalitas jangka pendek antara tingkat ROA, CAR dan BOPO terhadap tingkat FDR di Bank Syariah milik pemerintah Indonesia dari tahun 2009-2017. Hal ini sesuai dengan penelitian yang dilakukan oleh Kamalia Sani dan Maftukhatusolikhah (2015).

\section{Peramalan dan Analisis Struktural}

Pada bagian ini akan dijelaskan tentang peramalan dan analisis struktur dari peramalan dari model VECM(2). Sebelum membahas tentang analisa hasil peramalan akan dijelaskan terlebih dahulu tentang analisis struktural yang meliputi analisa Impulse Response Function (IRF) dan dekomposisi variansi. Analisa Impulse Response Function (IRF) merupakan hasil plot dari impulseresponse (IRF) di mana terdapat sembilan plot Impulse Response Function (IRF) untuk 10 periode ke depan, yang mana menjelaskan secara visual tanggapan (response) suatu variabel yang timbul karena adanya guncangan (shock/impulse) sebesar satu standar deviasi baik dari dirinya sendiri maupun dari variabel lain.
Analisa Impulse Response Function

IRF Tingkat ROA Terhadap ROA

Untuk hasil analisa Impulse Response Function (IRF) tingkat ROA terhadap ROA pada Bank Syariah milik pemerintah Indonesia dari tahun 2007-2017 sebagai berikut :

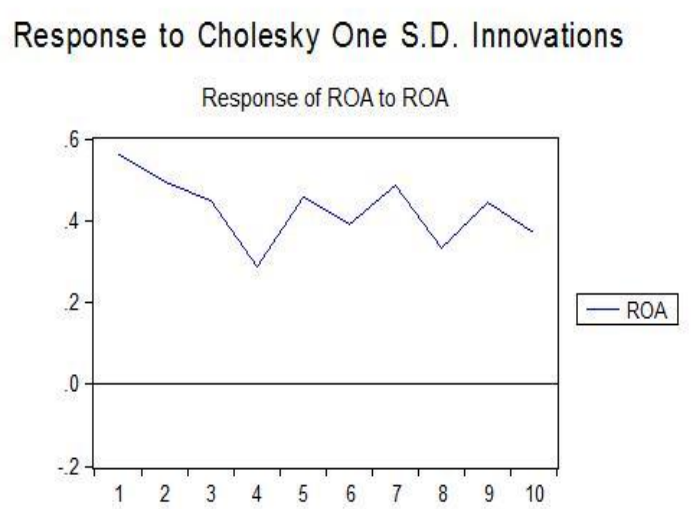

Gambar 1. IRF ROA terhadap ROA Sumber : Tabel 1, 2, 3, 4 (Data Diproses)

Respons tingkat ROA terhadap guncangan dari dirinya sendiri pada periode satu cukup besar, yaitu 0,56. Meskipun pada periode ketiga sempat mengalami penurunan sebesar 0,45 ; namun hingga periode 10 respons terhadap guncangan (dari dirinya sendiri) mengalami stagnan. Ini berarti bahwa setelah periode dua reaksi tingkat ROA terhadap guncangan dari dirinya sendiri cenderung stagnan ke arah positif.

IRF Tingkat ROA Terhadap CAR 
Untuk hasil analisa Impulse Response Function (IRF) tingkat ROA terhadap CAR pada Bank Syariah milik pemerintah Indonesia dari tahun 2007-2017 sebagai berikut :

\section{Response to Cholesky One S.D. Innovations}

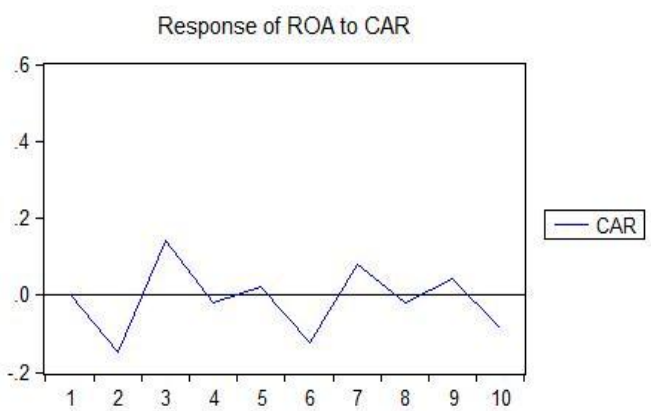

Gambar 2. IRF ROA terhadap CAR

Sumber : Tabel 1, 2, 3, 4 (Data Diproses)

Respons tingkat ROA terhadap CAR pada periode satu yaitu 0,00 . Kemudian pada periode keenam terjadi penurunan sebesar -0,12; namun hingga periode 10 respons terhadap guncangan CAR mengalami stagnan. Ini berarti bahwa setelah periode dua reaksi tingkat ROA terhadap guncangan CAR cenderung stagnan di area positif dan negatif.

\section{IRF Tingkat ROA Terhadap BOPO}

Untuk hasil analisa Impulse Response Function (IRF) tingkat ROA terhadap BOPO pada Bank Syariah milik pemerintah Indonesia dari tahun 20072017 sebagai berikut :

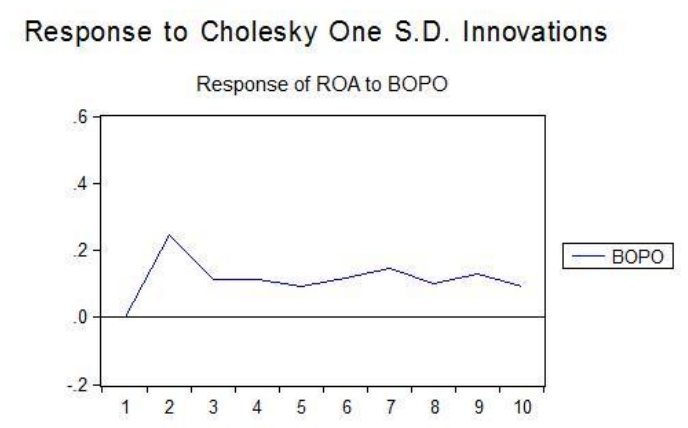

Gambar 3. IRF ROA terhadap BOPO Sumber : Tabel 1, 2, 3, 4 (Data Diproses)

Respons tingkat ROA terhadap BOPO pada periode satu yaitu 0,00 . Kemudian pada periode kedua terjadi peningkatan sebesar 0,24; namun hingga periode 10, respons terhadap guncangan BOPO mengalami stagnan. Ini berarti bahwa setelah periode dua reaksi tingkat ROA terhadap guncangan BOPO cenderung stagnan di area positif.

\section{IRF Tingkat ROA Terhadap FDR}

Untuk hasil analisa Impulse Response Function (IRF) tingkat ROA terhadap FDR pada Bank Syariah milik pemerintah Indonesia dari tahun 2007-2017 sebagai berikut :

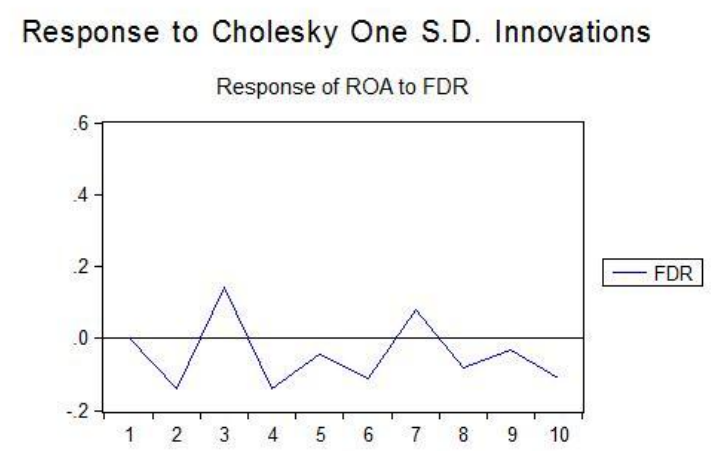


Gambar 4. IRF ROA terhadap FDR

Sumber : Tabel 1, 2, 3, 4 (Data Diproses) Respons tingkat ROA terhadap FDR pada periode satu yaitu 0,00. Kemudian pada periode kedua terjadi penurunan sebesar $-0,14$; namun hingga periode 10 , respons terhadap guncangan FDR mengalami stagnan. Ini berarti bahwa setelah periode dua reaksi tingkat ROA terhadap guncangan FDR cenderung stagnan di area positif dan negatif.

IRF Tingkat CAR Terhadap ROA

Untuk hasil analisa Impulse Response Function (IRF) tingkat CAR terhadap ROA pada Bank Syariah milik pemerintah Indonesia dari tahun 2007-2017 sebagai berikut :

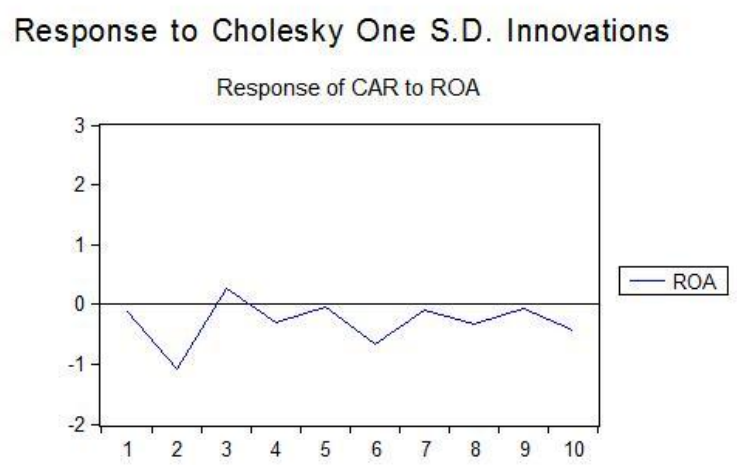

Gambar 5. IRF CAR terhadap ROA Sumber : Tabel 1, 2, 3, 4 (Data Diproses)

Respons tingkat CAR terhadap ROA pada periode satu yaitu $-0,1$. Kemudian pada periode ketiga terjadi peningkatan sebesar 0,3 selanjutnya pada periode empat terjadi penurunan sebesar -0,3; namun hingga periode lima sampai 10 , respons terhadap guncangan ROA mengalami stagnan. Ini berarti bahwa setelah periode lima reaksi tingkat ROA terhadap guncangan ROA cenderung stagnan di area negatif.

\section{IRF Tingkat CAR Terhadap CAR}

Untuk hasil analisa Impulse Response Function (IRF) tingkat CAR terhadap dirinya sendiri pada Bank Syariah milik pemerintah Indonesia dari tahun 20072017 sebagai berikut :

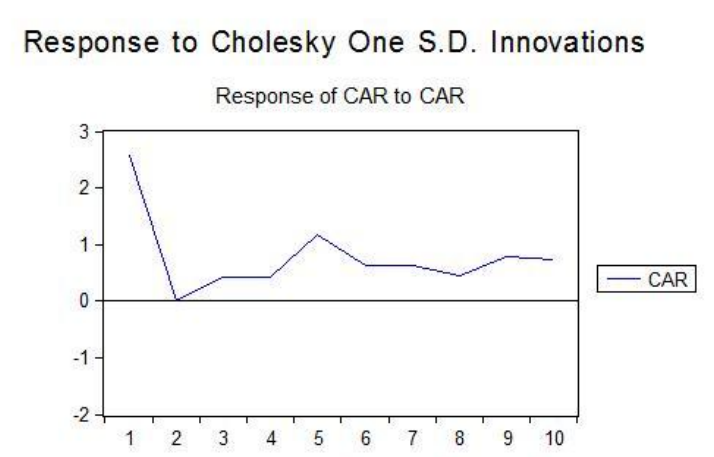

Gambar 6. IRF CAR terhadap CAR Sumber : Tabel 1, 2, 3, 4 (Data Diproses)

Respons tingkat CAR terhadap dirinya sendiri pada periode satu yaitu 2,6. Kemudian pada periode kedua terjadi penurunan 0,0 selanjutnya pada periode ketiga terjadi peningkatan sebesar 0,4; namun hingga periode keempat sampai 10, respons terhadap guncangan CAR mengalami stagnan. Ini berarti bahwa setelah periode keempat sampai 10 reaksi tingkat CAR terhadap guncangan dirinya sendiri (ROA) cenderung stagnan di area positif. 
IRF Tingkat CAR Terhadap BOPO

Untuk hasil analisa Impulse Response Function (IRF) tingkat CAR terhadap BOPO pada Bank Syariah milik pemerintah Indonesia dari tahun 20072017 sebagai berikut :

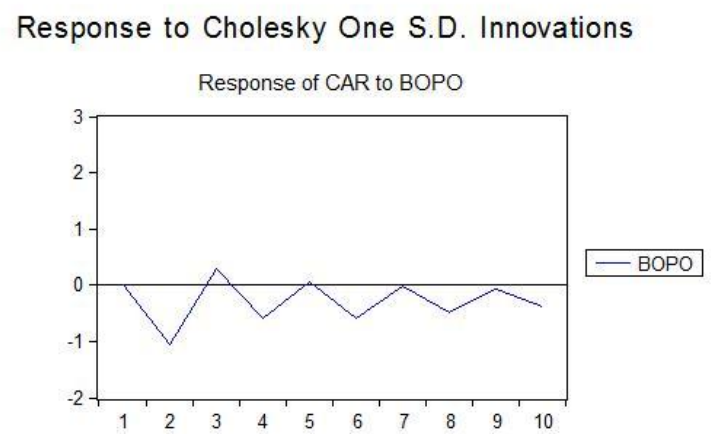

Gambar 7. IRF CAR terhadap BOPO

Sumber : Tabel 1, 2, 3, 4 (Data Diproses)

Respons tingkat CAR terhadap BOPO pada periode satu yaitu 0,0 . Kemudian pada periode kedua terjadi penurunan di $-1,0$ selanjutnya pada periode ketiga terjadi peningkatan sebesar 0,3 ; namun hingga periode keempat sampai 10, respons terhadap guncangan CAR mengalami stagnan. Ini berarti bahwa setelah periode keempat sampai 10 reaksi tingkat CAR terhadap BOPO cenderung stagnan di area negatif.

\section{IRF Tingkat CAR Terhadap FDR}

Untuk hasil analisa Impulse Response Function (IRF) tingkat CAR terhadap FDR pada Bank Syariah milik pemerintah
Indonesia dari tahun 2007-2017 sebagai berikut :

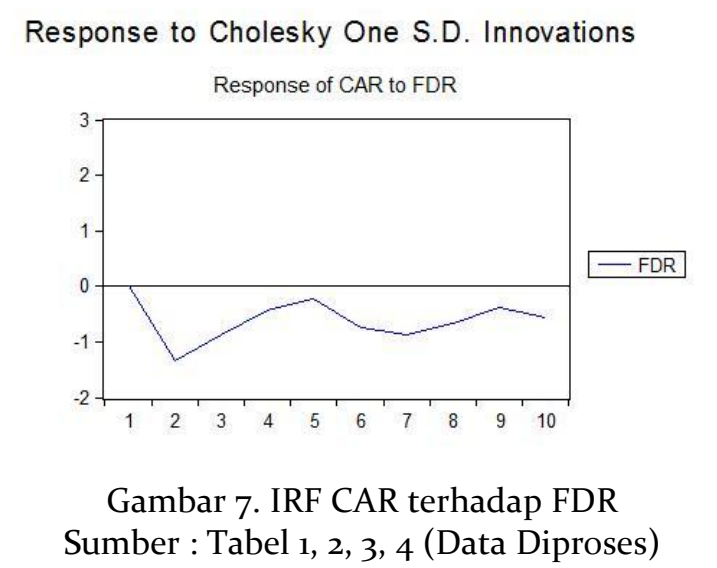

Respons tingkat CAR terhadap FDR pada periode satu yaitu 0,0. Kemudian pada periode kedua terjadi penurunan di $-1,3$ selanjutnya pada periode kelima terjadi peningkatan namun tetap di area negatif sebesar -0,2; namun hingga periode keenam sampai 10, respons terhadap guncangan FDR mengalami stagnan. Ini berarti bahwa setelah periode keenam sampai 10 reaksi tingkat CAR terhadap FDR cenderung stagnan di area negatif.

IRF Tingkat BOPO Terhadap ROA

Untuk hasil analisa Impulse Response Function (IRF) tingkat BOPO terhadap ROA pada Bank Syariah milik pemerintah Indonesia dari tahun 2007-2017 sebagai berikut : 


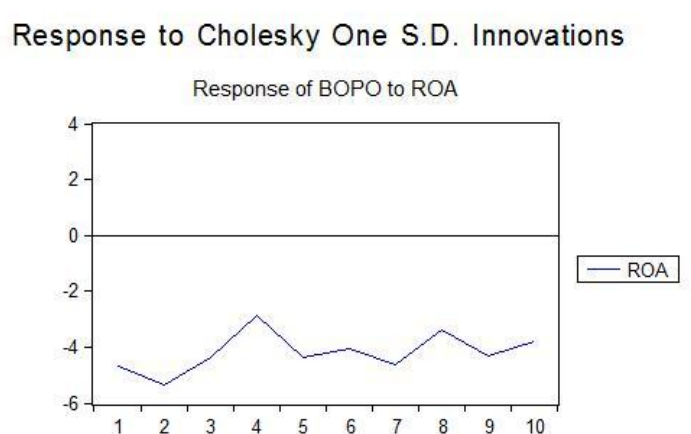

Gambar 8. IRF BOPO terhadap ROA

Sumber : Tabel 1, 2, 3, 4 (Data Diproses)

Respons tingkat BOPO terhadap ROA pada periode satu sampai 10 , respons terhadap guncangan ROA mengalami stagnan. Ini berarti bahwa setelah periode satu sampai 10 reaksi tingkat BOPO terhadap ROA cenderung stagnan di area negatif.

IRF Tingkat BOPO Terhadap CAR

Untuk hasil analisa Impulse Response Function (IRF) tingkat BOPO terhadap CAR pada Bank Syariah milik pemerintah Indonesia dari tahun 2007-2017 sebagai berikut :

Response to Cholesky One S.D. Innovations

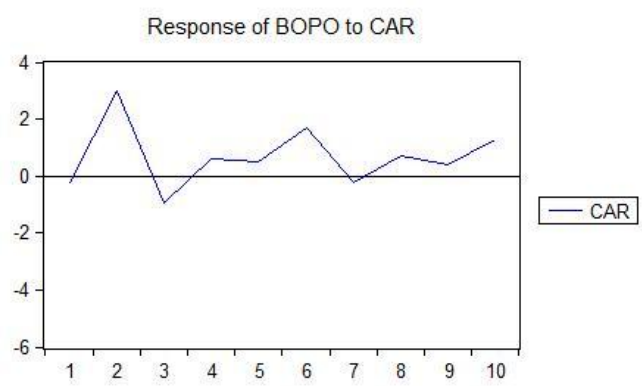

Gambar 9. IRF BOPO terhadap CAR Sumber : Tabel 1, 2, 3, 4 (Data Diproses)
Respons tingkat BOPO terhadap CAR pada periode satu sampai 10, respons terhadap guncangan FDR mengalami stagnan. Ini berarti bahwa setelah periode satu sampai 10 reaksi tingkat BOPO terhadap CAR cenderung stagnan di area positif dan negatif.

IRF Tingkat BOPO Terhadap BOPO

Untuk hasil analisa Impulse Response Function (IRF) tingkat BOPO terhadap BOPO pada Bank Syariah milik pemerintah Indonesia dari tahun 20072017 sebagai berikut :

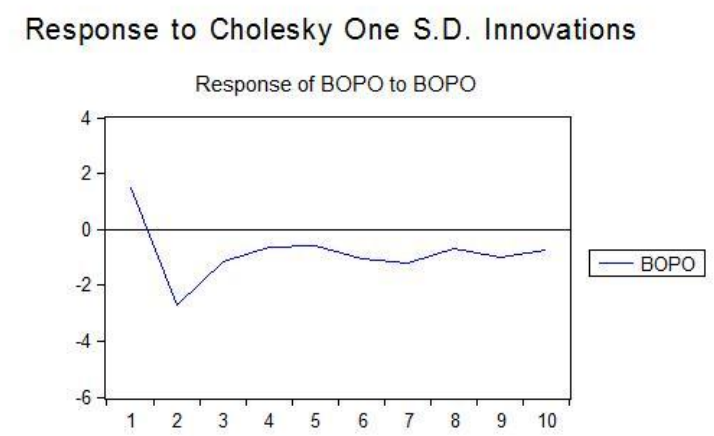

Gambar 10. IRF BOPO terhadap BOPO Sumber : Tabel 1, 2, 3, 4 (Data Diproses)

Respons tingkat BOPO terhadap BOPO pada periode satu sampai 10, respons terhadap guncangan BOPO mengalami stagnan. Ini berarti bahwa setelah periode satu sampai 10 reaksi tingkat BOPO terhadap BOPO cenderung stagnan di area negatif. 
IRF Tingkat BOPO Terhadap FDR

Untuk hasil analisa Impulse Response Function (IRF) tingkat BOPO terhadap FDR pada Bank Syariah milik pemerintah Indonesia dari tahun 2007-2017 sebagai berikut :

Response to Cholesky One S.D. Innovations

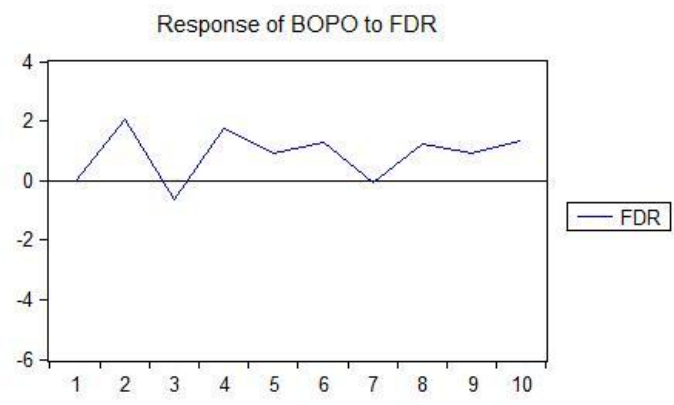

Gambar 11. IRF BOPO terhadap FDR Sumber : Tabel 1, 2, 3, 4 (Data Diproses)

Respon tingkat BOPO terhadap FDR pada periode satu sampai 10, respon terhadap guncangan FDR mengalami stagnan. Ini berarti bahwa setelah periode satu sampai 10 reaksi tingkat BOPO terhadap FDR cenderung stagnan di area positif.

IRF Tingkat FDR Terhadap ROA

Untuk hasil analisa Impulse Response Function (IRF) tingkat FDR terhadap ROA pada Bank Syariah milik pemerintah Indonesia dari tahun 2007-2017 sebagai berikut :

\section{Response to Cholesky One S.D. Innovations Response of FDR to ROA}

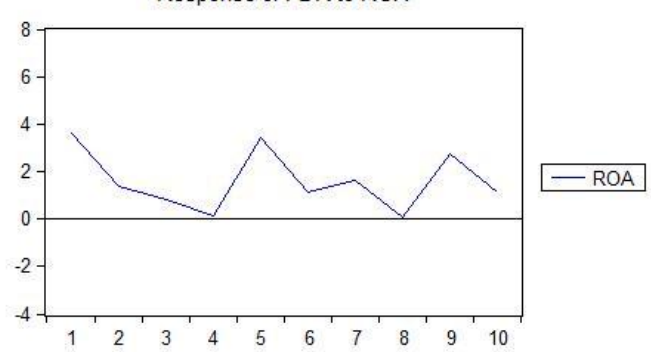

Gambar 12. IRF FDR terhadap ROA Sumber : Tabel 1, 2, 3, 4 (Data Diproses)

Respon tingkat FDR terhadap ROA pada periode satu sampai 10, respon terhadap guncangan FDR mengalami stagnan. Ini berarti bahwa setelah periode satu sampai 10 reaksi tingkat FDR terhadap ROA cenderung stagnan di area positif.

\section{IRF Tingkat FDR Terhadap CAR}

Untuk hasil analisa Impulse Response Function (IRF) tingkat FDR terhadap CAR pada Bank Syariah milik pemerintah Indonesia dari tahun 2007-2017 sebagai berikut :

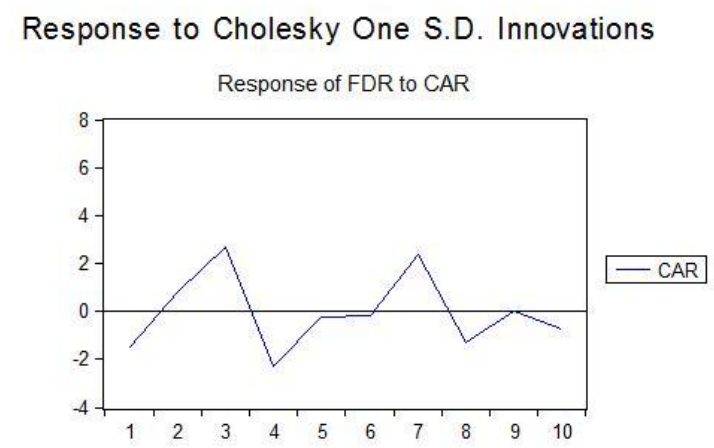

Gambar 13. IRF FDR terhadap CAR 
Sumber : Tabel 1, 2, 3, 4 (Data Diproses)

Respon tingkat FDR terhadap CAR pada periode satu sampai 10 , respon terhadap guncangan FDR mengalami stagnan. Ini berarti bahwa setelah periode satu sampai 10 reaksi tingkat FDR terhadap CAR cenderung stagnan di area positif dan negatif.

IRF Tingkat FDR Terhadap BOPO

Untuk hasil analisa Impulse Response Function (IRF) tingkat FDR terhadap CAR pada Bank Syariah milik pemerintah Indonesia dari tahun 2007-2017 sebagai berikut :

Response to Cholesky One S.D. Innovations

Response of FDR to BOPO

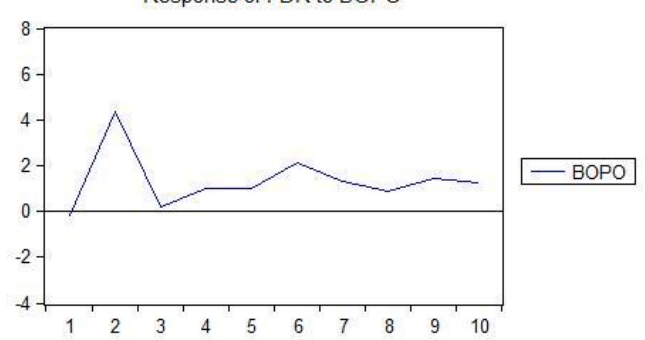

Gambar 14. IRF FDR terhadap CAR

Sumber : Tabel 1, 2, 3, 4 (Data Diproses)

Respons tingkat FDR terhadap BOPO pada periode satu sampai 10, respon terhadap guncangan BOPO mengalami stagnan. Ini berarti bahwa setelah periode satu sampai 10 reaksi tingkat FDR terhadap BOPO cenderung stagnan di area positif.
IRF Tingkat FDR Terhadap FDR

Untuk hasil analisa Impulse Response Function (IRF) tingkat FDR terhadap FDR pada Bank Syariah milik pemerintah Indonesia dari tahun 2007-2017 sebagai berikut :

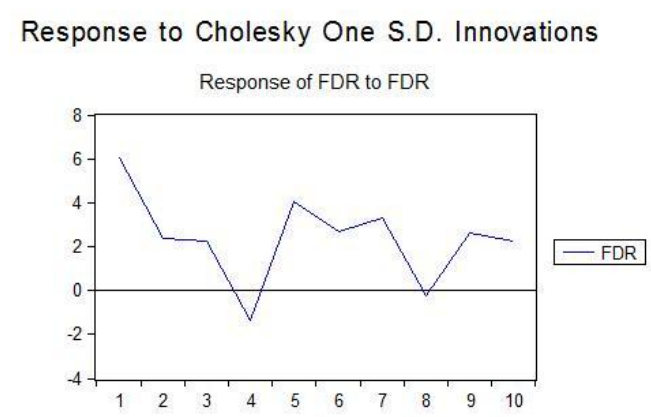

Gambar 15. IRF FDR terhadap FDR Sumber : Tabel 1, 2, 3, 4 (Data Diproses)

Respon tingkat FDR terhadap FDR pada periode satu sampai 10, respons terhadap guncangan BOPO mengalami stagnan. Ini berarti bahwa setelah periode satu sampai 10 reaksi tingkat FDR terhadap FDR cenderung stagnan di area positif.

\section{Dekomposisi Variansi}

Analisa dekomposisi variansi sering disebut sebagai sebuah analisa forecast error decomposition variance (FEDV). Adapun hasil analisa FEDV untuk 10 periode dari masing-masing variabel yaitu sebagai berikut :

Table 14. Forecast Error Decomposition Variance (FEDV) untuk variabel ROA

\begin{tabular}{|c|c|c|c|c|c|}
\hline Periode & S.E. & ROA & CAR & BOPO & FDR \\
\hline 1 & 0,56 & 100,00 & o,oo & o,oo & o,oo \\
\hline
\end{tabular}




\begin{tabular}{|c|c|c|c|c|c|}
\hline 2 & 0,81 & 84,65 & 3,38 & 9,07 & 2,90 \\
\hline 3 & 0,96 & 83,08 & 4,69 & 7,98 & 4,25 \\
\hline 4 & 1,01 & 81,76 & 4,20 & 8,31 & 5,71 \\
\hline 5 & 1,12 & 84,10 & 3,50 & 7,54 & 4,86 \\
\hline 6 & 1,20 & 83,39 & 4,07 & 7,51 & 5,04 \\
\hline 7 & 1,31 & 84,02 & 3,82 & 7,55 & 4,62 \\
\hline 8 & 1,36 & 84,19 & 3,57 & 7,59 & 4,65 \\
\hline 9 & 1,43 & 84,87 & 3,29 & 7,62 & 4,21 \\
\hline 10 & 1,49 & 84,76 & 3,37 & 7,44 & 4,44 \\
\hline
\end{tabular}

Sumber : Table 1, 2, 3, 4 (Data diproses)

Tabel 14 merupakan rangkuman hasil analisis FEDV untuk tingkat ROA dari guncangan yang diberikan oleh masingmasing variabel termasuk dirinya sendiri. Analisa FEDV yang dapat diambil dari tabel 14 menyatakan bahwa dalam jangka pendek yaitu periode ketiga: guncangan terhadap dirinya sendiri mengakibatkan 83,08\% fluktuasi dalam tingkat ROA, dan guncangan terhadap tingkat CAR mengakibatkan 4,69\% fluktuasi dalam tingkat ROA, sedangkan tingkat BOPO mengakibatkan 7,99\% fluktuasi dalam tingkat ROA serta tingkat FDR mengakibatkan 4,25\% dari fluktuasi dalam tingkat ROA di bank syariah milik pemerintah Indonesia dari tahun 20092017. Dilain pihak dalam jangka panjang yaitu pada period ke-10; guncangan terhadap dirinya sendiri semakin meningkat fluktuasinya dalam tingkat ROA, sedangkan guncangan tingkat CAR semakin melemah sebesar 3,37\% dalam tingkat ROA, sementara itu untuk tingkat BOPO melemah sebesar 7,4\% dalam tingkat ROA serta tingkat FDR menguat sebesar $4,4 \%$ dalam tingkat ROA. Kemudian untuk analisa FEDV untuk tingkat CAR dapat dlihat dalam tabel berikut ini :

Table 15. Forecast Error Decomposition Variance (FEDV) untuk variabel CAR

\begin{tabular}{|c|c|c|c|c|c|}
\hline Periode & S.E. & ROA & CAR & BOPO & FDR \\
\hline 1 & 2,57 & 0,22 & 99,78 & 0,00 & 0,00 \\
\hline 2 & 3,27 & 11,07 & 61,78 & 10,31 & 16,84 \\
\hline 3 & 3,43 & 10,59 & 57,42 & 10,13 & 21,86 \\
\hline 4 & 3,54 & 10,63 & 55,18 & 12,20 & 21,99 \\
\hline 5 & 3,74 & 9,56 & 59,37 & 10,98 & 20,09 \\
\hline 6 & 3,97 & 11,25 & 55,34 & 12,02 & 21,39 \\
\hline 7 & 4,11 & 10,53 & 53,93 & 11,20 & 24,34 \\
\hline 8 & 4,23 & 10,54 & 52,03 & 11,92 & 25,52 \\
\hline 9 & 4,32 & 10,11 & 53,21 & 11,48 & 25,23 \\
\hline 10 & 4,46 & 10,44 & 52,70 & 11,51 & 25,35 \\
\hline
\end{tabular}

Sumber : Table 1, 2, 3, 4 (Data diproses)

Tabel 15 merupakan rangkuman hasil analisis FEDV untuk tingkat CAR dari guncangan yang diberikan oleh masingmasing variabel termasuk dirinya sendiri. Analisa FEDV yang dapat diambil dari tabel 15 menyatakan bahwa dalam jangka pendek yaitu periode ketiga: guncangan terhadap dirinya sendiri mengakibatkan 10,59\% fluktuasi dalam tingkat CAR, dan guncangan terhadap dirinya sendiri mengakibatkan 57,42\% fluktuasi dalam tingkat CAR, sedangkan tingkat BOPO mengakibatkan 10,13\% 
fluktuasi dalam tingkat CAR serta tingkat FDR mengakibatkan 21,86\% dari fluktuasi dalam tingkat CAR di bank syariah milik pemerintah Indonesia dari tahun 2009-2017. Di lain pihak dalam jangka panjang yaitu pada period ke-10; guncangan terhadap dirinya sendiri semakin meningkat fluktuasinya dalam tingkat ROA sebesar 10,44 dalam tingkat CAR, sedangkan guncangan tingkat CAR terhadap dirinya sendiri semakin melemah sebesar 52,70\% dalam tingkat CAR, sementara itu untuk tingkat BOPO menguat sebesar $11,51 \%$ dalam tingkat CAR serta tingkat FDR menguat sebesar 25,35\% dalam tingkat CAR. Kemudian untuk analisa FEDV untuk tingkat BOPO dapat dlihat dalam tabel berikut ini :

Table 16. Forecast Error Decomposition Variance (FEDV) untuk variabel BOPO

\begin{tabular}{|c|c|c|c|c|c|}
\hline Periode & S.E. & ROA & CAR & BOPO & FDR \\
\hline 1 & 4,90 & 90,66 & 0,26 & 9,09 & o,oo \\
\hline 2 & 8,54 & 68,82 & 12,25 & 13,10 & 5,83 \\
\hline 3 & 9,73 & 73,25 & 10,40 & 11,47 & 4,89 \\
\hline 4 & 10,34 & 72,75 & 9,54 & 10,57 & 7,13 \\
\hline 5 & 11,27 & 75,99 & 8,24 & 9,14 & 6,63 \\
\hline 6 & 12,21 & 75,72 & 8,97 & 8,54 & 6,76 \\
\hline 7 & 13,11 & 78,04 & 7,80 & 8,28 & 5,87 \\
\hline 8 & 13,63 & 78,35 & 7,48 & 7,93 & 6,24 \\
\hline 9 & 14,35 & 79,53 & 6,81 & 7,65 & 6,01 \\
\hline 10 & 14,98 & 79,49 & 6,96 & 7,27 & 6,28 \\
\hline
\end{tabular}

Source : Table 1, 2, 3, 4 (Data processed)

Tabel 16 merupakan rangkuman hasil analisis FEDV untuk tingkat BOPO dari guncangan yang diberikan oleh masingmasing variabel termasuk dirinya sendiri.
Analisa FEDV yang dapat diambil dari tabel 16 menyatakan bahwa dalam jangka pendek yaitu periode ketiga: guncangan terhadap dirinya sendiri mengakibatkan 11,47\% fluktuasi dalam tingkat BOPO, dan guncangan terhadap ROA mengakibatkan 73,26\% fluktuasi dalam tingkat ROA, sedangkan tingkat CAR mengakibatkan 10,40\% fluktuasi dalam tingkat BOPO serta tingkat FDR mengakibatkan 4,89\% dari fluktuasi dalam tingkat BOPO di bank syariah milik pemerintah Indonesia dari tahun 20092017. Di lain pihak dalam jangka panjang yaitu pada period ke-10; guncangan terhadap dirinya sendiri semakin meningkat fluktuasinya dalam tingkat ROA sebesar 79,49 dalam tingkat BOPO, sedangkan guncangan tingkat BOPO terhadap dirinya sendiri semakin melemah sebesar 7,27\% dalam tingkat BOPO, sementara itu untuk tingkat CAR melemah menjadi 6,96\% dalam tingkat BOPO serta tingkat FDR melemah menjadi $6,28 \%$ dalam tingkat BOPO. Kemudian untuk analisa FEDV untuk tingkat FDR dapat dlihat dalam tabel berikut ini :

Table 17. Forecast Error Decomposition Variance (FEDV) untuk variabel FDR

\begin{tabular}{|c|c|c|c|c|c|}
\hline Periode & S.E. & ROA & CAR & BOPO & FDR \\
\hline 1 & 7,22 & 25,40 & 4,08 & 0,05 & 70,47 \\
\hline 2 & 8,91 & 19,03 & 3,52 & 24,05 & 53,40 \\
\hline 3 & 9,62 & 17,05 & 10,92 & 20,66 & 51,37 \\
\hline
\end{tabular}




\begin{tabular}{|c|c|c|c|c|c|}
\hline 4 & 10,04 & 15,69 & 15,23 & 19,99 & 49,09 \\
\hline 5 & 11,39 & 21,15 & 11,88 & 16,34 & 50,63 \\
\hline 6 & 11,94 & 20,11 & 10,84 & 18,00 & 51,05 \\
\hline 7 & 12,79 & 19,18 & 12,93 & 16,78 & 51,11 \\
\hline 8 & 12,89 & 18,89 & 13,74 & 16,98 & 50,39 \\
\hline 9 & 13,52 & 21,38 & 12,49 & 16,61 & 49,51 \\
\hline 10 & 13,82 & 21,11 & 12,24 & 16,71 & 49,95 \\
\hline
\end{tabular}

Source : Table 1, 2, 3, 4 (Data processed)

Tabel 17 merupakan rangkuman hasil analisis FEDV untuk tingkat FDR dari guncangan yang diberikan oleh masingmasing variabel termasuk dirinya sendiri. Analisa FEDV yang dapat diambil dari tabel 17 menyatakan bahwa dalam jangka pendek yaitu periode ketiga: guncangan terhadap dirinya sendiri mengakibatkan 51,37\% fluktuasi dalam tingkat FDR, dan guncangan terhadap ROA mengakibatkan 17,05\% fluktuasi dalam tingkat FDR, sedangkan tingkat CAR mengakibatkan 10,92\% fluktuasi dalam tingkat FDR serta tingkat BOPO mengakibatkan 20,66\% dari fluktuasi dalam tingkat FDR di bank syariah milik pemerintah Indonesia dari tahun 20092017. Di lain pihak dalam jangka panjang yaitu pada period ke-10; guncangan terhadap dirinya sendiri semakin meningkat fluktuasinya dalam tingkat ROA menjadi 21,11\% dalam tingkat FDR, sedangkan guncangan tingkat FDR terhadap dirinya sendiri semakin melemah menjadi 49,95\% dalam tingkat FDR, sementara itu untuk tingkat CAR meningkat menjadi $12,24 \%$ dalam tingkat FDR serta tingkat BOPO melemah menjadi 16,71\% dalam tingkat FDR.

\section{Hasil Ramalan}

Hasil ramalan dengan menggunakan $\operatorname{VECM(2)~untuk~} 10$ periode kedepan dapat dilihat pada gambar berikut ini :
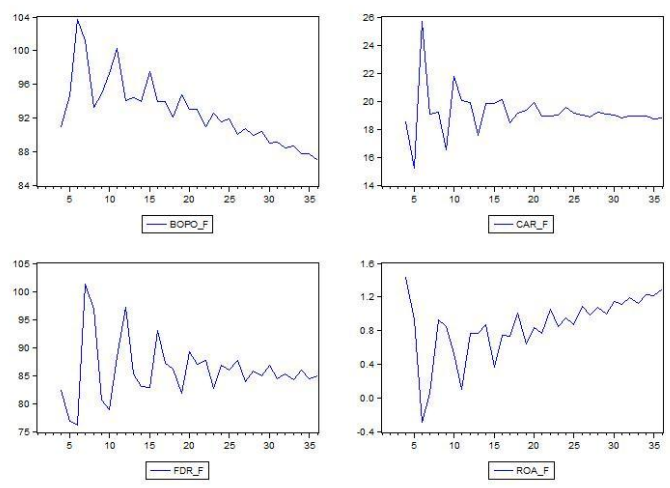

Gambar 16. Peramalan ROA, CAR, FDR dan BOPO 10 periode kedepan

Sumber : Tabel 1, 2, 3, 4 (Data Diproses)

Dari gambar di atas, diketahui yang diramalkan mengalami peningkatan yaitu tingkat ROA sedangkan yang mengalami pelemahan yaitu tingkat BOPO, disamping itu yang akan mengalami pertumbuhan stagnan yaitu tingkat CAR dan FDR pada bank syariah milik pemerintah Indonesia dari tahun 20092017. Berdasarkan gambar 16, maka dapat diperoleh nilai MAPE dari masing- 
masing variabel seperti yang ditunjukkan dalam tabel 18 berikut ini:

Tabel 18. Hasil keakuratan peramalan

\begin{tabular}{|l|c|}
\hline \multicolumn{1}{|c|}{ Rasio } & MAPE \\
\hline ROA & $99,98 \%$ \\
\hline CAR & $100,91 \%$ \\
\hline OEOI & $100,38 \%$ \\
\hline FDR & $3185,34 \%$ \\
\hline
\end{tabular}

Sumber : Tabel 1, 2, 3, 4 (Data Diproses)

Berdasarkan gambar 17, maka dapat diperoleh nilai MAPE dari masing-masing variabel seperti yang ditunjukkan dalam tabel 18. Pada tabel 18 dapat dilihat bahwa MAPE terkecil adalah variabel ROA. Ini artinya bahwa peramalan dengan menggunakan model $\operatorname{VECM(2)}$ lebih akurat jika diterapkan pada ROA (Return On Asset).

\section{SIMPULAN}

Berdasarkan hasil dan pembahasan, maka dapat dibuat kesimpulan sebagai berikut:

1. Berdasarkan spesifikasi model (analisis lag optimum) dan pemeriksaan model (uji serial korelasi residual), maka diperoleh model terbaik untuk data tingkat CAR, BOPO dan FDR terhadap ROA adalah $\operatorname{VECM}(2)$.

2. Berdasarkan VECM(2), diperoleh hasil analisis kausalitas sebagai berikut :

a. Terdapat hubungan kausalitas jangka pendek maupun jangka panjang antara tingkat ROA sebagai variabel dependen dan tingkat CAR, BOPO dan FDR sebagai variabel independen.

b. Tidak terdapat hubungan kausalitas jangka pendek antara tingkat ROA sebagai variabel dependen dengan tingkat CAR, BOPO dan FDR, namun sebaliknya terdapat hubungan jangka panjang antara tingkat ROA terhadap tingkat CAR, BOPO dan FDR.

c. Tidak terdapat hubungan kausalitas jangka pendek maupun jangka panjang antara tingkat ROA sebagai variabel dependen dengan tingkat CAR, BOPO dan FDR.

3. Berdasarkan analisis struktural dari $\operatorname{VECM(2),~dapat~dibuat~kesimpulan~}$ bahwa:

a. Respon dari masing-masing variabel terhadap guncangan yang berasal dari dirinya sendiri cukup signifikan, karena terjadi fluktuasi.

b. Respon dari tingkat ROA terhadap CAR, BOPO dan FDR sangat signifikan.

c. Secara umum, untuk analisis ke depan baik itu dalam jangka panjang maupun jangka pendek, tingkat ROA terhadap tingkat CAR, 
I Wayan Sunarya, Pengaruh Kecukupan Modal, Efisiensi dan Likuiditas Terhadap Rentabilitas di Bank Syariah Milik Pemerintah Indonesia

BOPO dan FDR saling mempengaruhi secara signifikan.

4. Hasil ramalan yang diperoleh dengan menggunakan VECM(2) cukup akurat, terutama untuk meramalkan tingkat ROA. Hal ini dapat dilihat dari MAPE dari tingkat ROA yang menunjukkan angka persentase terkecil dari keempat variabel.

Perlu diketahui untuk tingkat ROA yang ada di dalam bank syariah milik pemerintah Indonesia menunjukkan tingkat keuntungan yang dicapai oleh bank dalam periode tertentu yang bersumber dari total aset yang dimilikinya.

\section{DAFTAR PUSTAKA}

Anita Karisma Mastika Permatasari dan Dheasey Amboningtyas. 2017. The Influence of CAR, BOPO and FDR on ROA (Study on Conventional Bank Sub Sector Company 2012-2016 listed in BEI). Journal of Management 3(3):21-34

Adesola Adebola Ikudayisi dan Kabir Kayode Salman. 2018. Spatial Integration Of Maize Market In Nigeria - A Vector Error Correction Model. International Journal of Food and Agricultural Economics 2(3):7180

Adli Nazrian \& Paidi Hidayat. 2012. Studi Tentang Keputusan Nasabah Dalam Menabung Di Bank Sumut Cabang Usu Medan Metode Analytical Hierarchy Process (AHP). Jurnal Ekonomi dan Keuangan 1(1):14-21

Aris Fadjar, Hedwigis Esti R. dan Tri Prihatini EKP. 2013. Analisis Faktor Internal Dan
Eksternal Bank yang Mempengaruhi Profitabilitas Bank Umum Di Indonesia. Journal of Management and Business Review 10(1):63-67

Astri Faradila \& Ari Dewi Cahyati. 2013. Analisis Manajemen Laba pada Perbankan Syariah. Jurnal Riset Akuntansi \& Komputerisasi Akuntansi 4(1):57-74

Deden Edwar Yokeu Bernardin. 2016. Pengaruh CAR dan LDR Terhadap Beban Operasional Pendapatan Operasional. Jurnal Ecodemica $4(2): 232-241$

Didin Rasyidin Wahyu. 2016. Financing To Deposit Ratio (Fdr) sebagai salah satu penilaian kesehatan Bank Umum Syariah (Study Kasus Pada Bank BJB Syariah Cabang Serang). Jurnal Ekonomi Keuangan dan Bisnis Islam 7(1):19-36

Erma Kurniasih. 2016. Pengaruh Capital Adequacy Ratio, Non Performing Loan, Loan To Deposit Ratio, Efisiensi Operasi, Not Interest Margin Terhadap Finance Deposit Ratio (Studi Empiris pada Perusahaan Perbankan yang Listing di BEI tahun 2009 2014). Journal of Accounting 2(2):23-35

Fenandi Bilian \& Purwanto. 2017. Analisis Pengaruh CAR, NIM, BOPO dan LDR Terhadap Profitabilitas Bank Persero. Firm Journal of Management Studies 2(1):155168

Hamilton, J. D. 1990. Analysis of time series subject to changes in regime. Journal of Econometrics, (45) : 39-70.

Kamalia Sani dan Maftukhatusolikhah. 2015. Pengaruh Capital Adequacy Ratio (CAR), BOPO, Return on Asset Terhadap Finance Deposit Ratio pada Bank Umum Syariah Di Indonesia 2011-2013. I-Economics Journal 1(1):34-45

Lexy Janzen Sinay. 2014. Vector Error Correction Model Approach to Analysis of the relationship of Inflation, BI Rate and US Dollar. Jurnal Barekeng 8(2):9-18 
Mawardi, Wisnu. 2005. Analisis Faktor-faktor yang Mempengaruhi Kinerja Keuangan Bank Umum di Indonesia (Studi Kasus Pada Bank Umum dengan Total Assets Kurang dari 1 Trilliun). Jurnal Bisnis Strategi 3(3):84-94

Muhammad Yusuf Wibisono dan Salamah Wahyuni. 2017. Pengaruh CAR, NPF, BOPO, FDR Terhadap ROA yang dimediasi oleh NOM. Journal of Business and Management 17(1):41-62

Ntebogang Dinah Moroke, Janine Mududdem Petersen dan Mark Petersen. 2014. A Multivariate Time Series Analysis of Household Debts during 2007-2009 Financial Crisis in South Africa: A Vector Error Correction Approach. Mediterranean Journal of Social Sciences 5(7):107-118

Nurma Sari. 2016. Manajemen Dana Bank Syariah. Jurnal Ilmu Syariah:Al-Maslahah 12(1):4561

Nur Gilang Giannini. 2013. Faktor yang mempengaruhi pembiayaan Mudharabah pada bank umum syariah di Indonesia. Accounting Analysis Journal 2(1):97-103

Rofikoh Rokhim dan Jubilant Arda Harmidy. 2013. Ownership Structure, Risk And Their Impact Towards Performances In Indonesian Syariah Bank. Finance and Banking Journal 15(1):22-37 